\title{
Zeolite-based selective potentiometric hydrogen sensor
}

\author{
Gunter Hagen, Ralf Moos \\ University of Bayreuth \\ Bayreuth Engine Research Center (BERC) \\ Functional Materials Group \\ D - 95440 Bayreuth
}

\begin{abstract}
:
Planar potentiometric gas sensors consisting of thin-film interdigital electrodes (IDE) and an ionconducting zeolite thick-film cover layer are manufactured. One electrode comprises a thin film metaloxide layer on top, which is in contact to the zeolite. Electromotive forces between the electrodes depend on temperature, gas concentrations and the sensor configuration (type of metal oxide layer / type of ions in the Pt-doped zeolite). Results of a Pt-Na-ZSM-5 on Au/AuPt electrodes measured at $400{ }^{\circ} \mathrm{C}$ are very promising with respect to selectivity and sensitivity towards hydrogen in the test gas.
\end{abstract}

Keywords: Potentiometric gas sensor, hydrogen, zeolites

\section{INTRODUCTION}

Zeolites are aluminosilicates with high inner surfaces and internal exchangeable cations. Their properties are widespread due to adsorption, catalysis or ion-conduction. For that, zeolites are promising materials for application in sensing devices [1]. Many electroceramic chemical gas sensors deal with zeolite cover layers for improving their selectivity [2].

Zeolite-based gas sensors (which use the zeolite and its ion conducting properties as functional material) are rarely discussed in the literature. In [3], the ionic mobility of a special zeolite depends on the gas concentration. The impedance of a zeolite thick-film measured with interdigital electrodes at high frequencies $(\sim 1 \mathrm{kHz})$ gets lower in presence of $\mathrm{NH}_{3}$. One assumes a $\mathrm{H}^{+}$-hopping mechanism inside the zeolite volume, which is supported by $\mathrm{NH}_{3}$. Ref. [4] describes an impedimetric hydrocarbon (HC) sensing effect. The setup of such a sensor is similar to [3]. The impedance of a zeolite thick-film on IDE is measured at about $300{ }^{\circ} \mathrm{C}$. But here, a measuring effect occurs at low frequencies $(\sim 20 \mathrm{~Hz})$. Responsible for that is a $\mathrm{Cr}_{2} \mathrm{O}_{3}$-interface between the electrodes and the Pt-doped ZSM-5 thick-film. The sensor mechanism is clearly attributed to electrode effects [5]. A potentiometric setup utilizing zeolite pellets is introduced for $\mathrm{HC}$ detection in [6]. The emf of a $\mathrm{Au} /\left(\mathrm{Na}_{2} \mathrm{CO}_{3}, \mathrm{BaCO}_{3}\right) / z e o l i t e / \mathrm{Au}$ cell, where the $\mathrm{Na}_{2} \mathrm{CO}_{3} / \mathrm{Au}$ system serves as the reference electrode, strongly depends on the $\mathrm{HC}$ concentration in a wet $\mathrm{CO}_{2} / \mathrm{O}_{2} / \mathrm{N}_{2}$ carrier gas. The response to $\mathrm{C}_{3} \mathrm{H}_{8}$ partial pressure changes of several decades is about $40 \mathrm{mV}$ with $t_{90}=1300 \mathrm{~s}$.

For serial applications planar sensor setups are useful. On the one hand, manufacturing processes (such as thick-film or thin film technologies) are much easier. On the other hand, response times are expected to be low due to fast gas diffusion through thin or porous functional materials. The present work deals with a planar $\mathrm{H}_{2}$ sensing device, comprising thin-film interdigital electrodes (IDE). On one of both electrodes, a thin metal-oxide layer works as gas dependent interface. The electrodes are connected by an ion conducting zeolite thick-film. A highly selective and sensitive hydrogen gas sensor is obtained.

\section{EXPERIMENTAL}

The presented sensor transducers consist of thin-film Au interdigital electrodes (thickness: $200 \mathrm{~nm}$, line $=$ space $=15 \mu \mathrm{m}$ ) on alumina substrates (Rubalit 710, CeramTec). Each electrode was manufactured in a separate lift-off process (Resist: Ti 35ES, microchemicals). The electrode materials are deposited by 
thermal evaporation. One electrode comprises an additional thin metal-oxide cover (a few $\mathrm{nm}$ ), which was achieved by evaporation of various base metals $(\mathrm{Cr}, \mathrm{Ti}, \mathrm{Pt})$ and subsequent oxidation.

As ion conducting phase, ZSM-5 zeolites with varying cations (SüdChemie / Tricat) were Pt-doped $(1.6 \mathrm{wt} \%)$ by wet ion-exchange and subsequent reduction. The reduction process (converting $\mathrm{Pt}^{2+}$ to elemental $\mathrm{Pt}^{0}$ ) was carried out either wet-chemically after [7] by the use of $\mathrm{NaBH}_{4}$ or in a $\mathrm{H}_{2} / \mathrm{N}_{2}$ gas flow [8]. The resulting highly dispersed Pt-clusters cause a high catalytic activity of the zeolite.

The zeolites were processed to screen-printable pastes by adding organic binders (Zschimmer \& Schwarz). These were applied as thick-films on the sensor transducers (covering the whole IDE area) and heat treated at $450^{\circ} \mathrm{C}$ for $6 \mathrm{~h}$. (Figure 1).
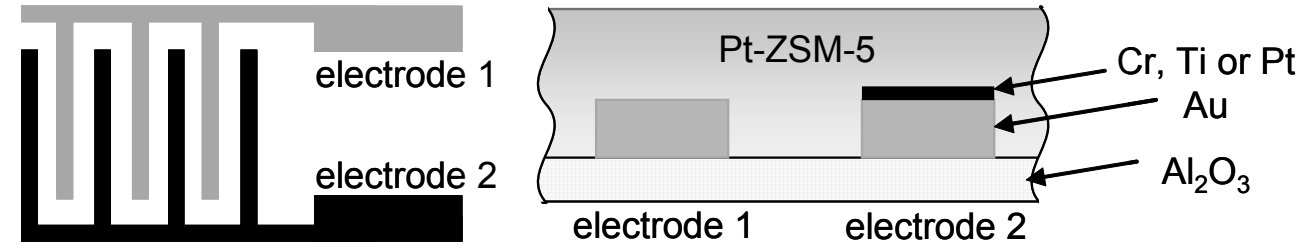

Figure 1: Scheme of the IDE structure (left) and cross section of a zeolite covered transducer (right)

Measurements are conducted in synthetic exhausts $\left(\mathrm{N}_{2}\right.$ balance, $\left.10 \% \mathrm{O}_{2}, 2.5 \% \mathrm{H}_{2} \mathrm{O}\right)$ with various test gases at different temperatures with a Keithley 2700 digital multimeter.

\section{RESULTS AND DISCUSSION}

For initial tests, different sensor transducers were prepared. Thereby, the oxide layer on one electrode varies. As base metals, $\mathrm{Cr}, \mathrm{Ti}$ and $\mathrm{Pt}$ are used. Each transducer was covered by a thick-film zeolite layer. Here, the materials vary in the type of exchangeable cations or the method of Pt-dopation. Completed sensors were investigated at different temperatures by measuring the electro-motive force (emf) over time and adding $1000 \mathrm{ppm} \mathrm{H}_{2}$ or $500 \mathrm{ppm} \mathrm{C}_{3} \mathrm{H}_{8}$. These configurations (special type of transducer with special type of zeolite) which show good $\mathrm{H}_{2}$ sensitivity are presented in table 1. (The results are achieved at different temperatures.)

Table 1: Investigated sensor configurations with high $\mathrm{H}_{2}$ sensitivity

\begin{tabular}{|c|c|c|c|c|}
\hline $\begin{array}{l}\text { Ion content } \\
\mathrm{Pt}-\mathrm{ZSM}-5\end{array}$ & $\begin{array}{c}\text { Interface } \\
\text { on one electrode }\end{array}$ & $T /{ }^{\circ} \mathrm{C}$ & $\begin{array}{c}\mathbf{\Delta} \mathbf{e m f} / \mathbf{m V} \\
1000 \mathrm{ppm} \mathrm{H} \mathrm{H}_{2}\end{array}$ & $\begin{array}{l}\text { cross-effects } \\
\text { (500 ppm HC) }\end{array}$ \\
\hline \multirow[t]{2}{*}{$100 \% \mathrm{Na}^{+}$} & \multirow[t]{2}{*}{$\mathrm{Cr}$} & 300 & 120 & Yes \\
\hline & & 350 & 120 & Yes \\
\hline \multirow[t]{2}{*}{$100 \% \mathrm{H}^{+}$} & \multirow[t]{2}{*}{$\mathrm{Cr}$} & 300 & 125 & Yes \\
\hline & & 350 & 90 & Yes \\
\hline \multirow[t]{2}{*}{$100 \% \mathrm{Na}^{+}$} & \multirow[t]{2}{*}{$\mathrm{Ti}$} & 350 & 100 & Yes \\
\hline & & 400 & 57 & Yes \\
\hline \multirow[t]{2}{*}{$100 \% \mathrm{Na}^{+}$} & \multirow[t]{2}{*}{$\mathrm{Pt}$} & 350 & 190 & Small \\
\hline & & 400 & 151 & Small \\
\hline \multirow{2}{*}{$\begin{array}{l}85 \% \mathrm{NH}_{4}^{+}, \\
15 \% \mathrm{H}^{+}\end{array}$} & \multirow[t]{2}{*}{$\mathrm{Pt}$} & 350 & 289 & Yes \\
\hline & & 600 & 121 & Yes \\
\hline \multirow{3}{*}{$\begin{array}{l}85 \% \mathrm{NH}_{4}^{+}, \\
15 \% \mathrm{H}^{+}\end{array}$} & \multirow[t]{3}{*}{$\mathrm{Cr}$} & 300 & 188 & Yes \\
\hline & & 350 & 173 & Small \\
\hline & & 400 & 146 & Small \\
\hline
\end{tabular}

All sensors of table 1 show a relatively high signal change towards $\mathrm{H}_{2}$. Some of them also respond towards $\mathrm{C}_{3} \mathrm{H}_{8}$. 
In a next step, the most promising configuration, which is a Pt-Na-ZSM-5 cover on Au/AuPt electrodes, was taken into further consideration for extended cross-sensitivity tests. This very promising result is given in figure 2.

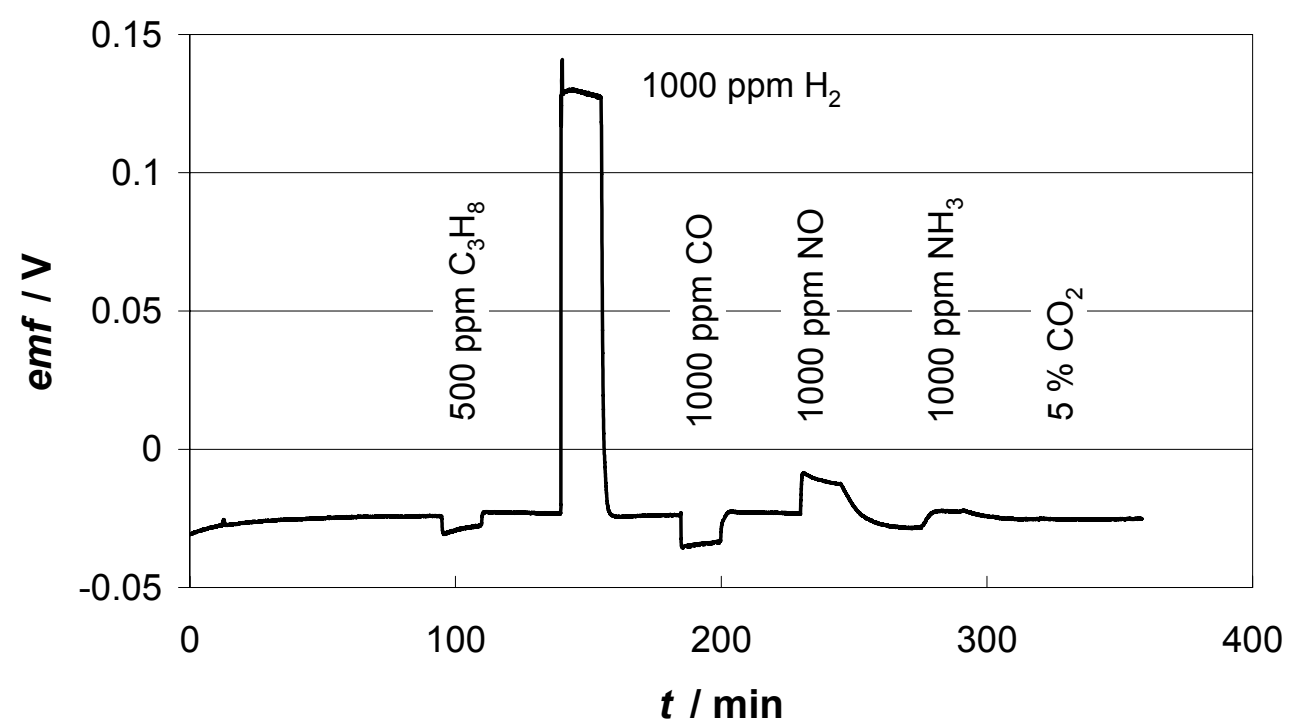

Figure 2: Electromotive force of a planar potentiometric zeolite gas sensor with Pt-Na-ZSM-5 on Au/AuPt electrodes $\left(400{ }^{\circ} \mathrm{C}, 10 \% \mathrm{O}_{2}, 2.5 \% \mathrm{H}_{2} \mathrm{O}\right.$ in $\mathrm{N}_{2}$ base gas)

A strong and very fast increase of the measured voltage occurs when $1000 \mathrm{ppm} \mathrm{H}_{2}$ are admixed. The sensor shows only small cross-sensitivities towards propane, $\mathrm{CO}, \mathrm{NO}, \mathrm{NH}_{3}$ or $\mathrm{CO}_{2}$. Figure 3 gives a simple view on the response kinetics of this result.
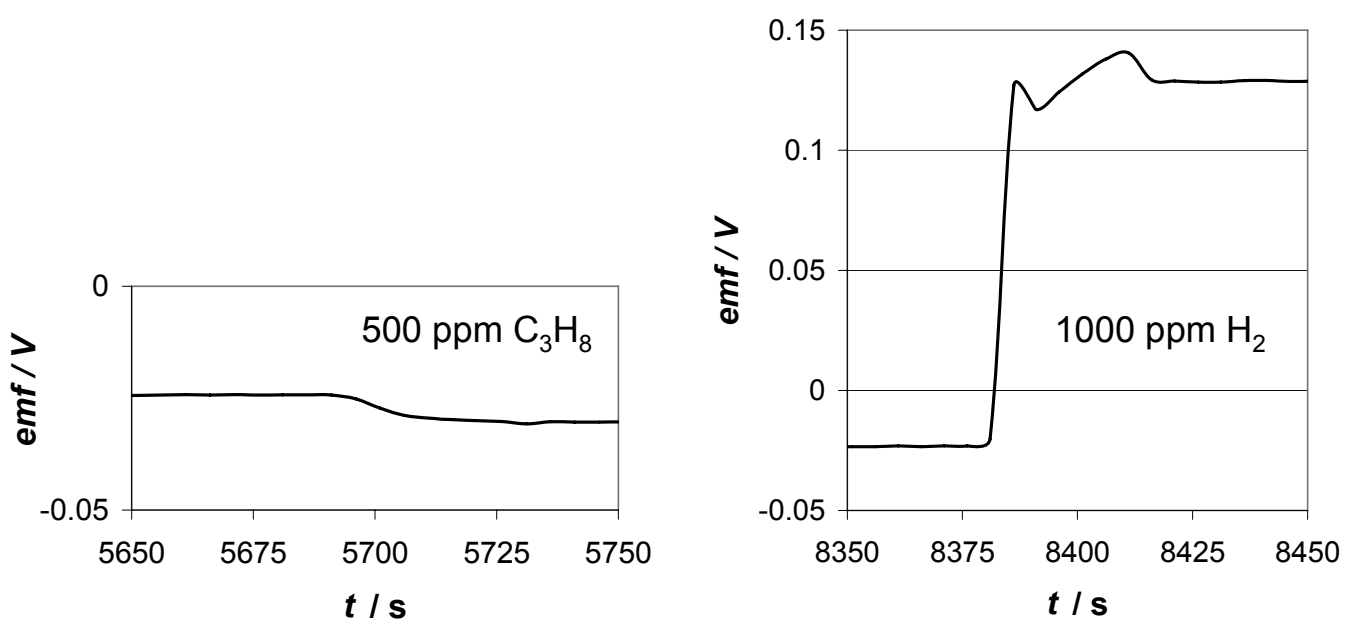

Figure 3: Details of the measurement in figure 2. Left: emf change towards $500 \mathrm{ppm} \mathrm{C}_{3} \mathrm{H}_{8}$, right: 1000 ppm $\mathrm{H}_{2}$ (irregularities might be caused by dosing problems of the test bench).

The detailed views on the measurement result reveal that stable emf-values are obtained about $25 \mathrm{~s}$ after admixing the test gases.

Further investigations should deal likewise with theoretical understanding of the sensor mechanism and the transfer of this sensor principle to low-cost production methods by integration a heating element and some signal processing. 


\section{REFERENCES}

[1] K. Sahner, G. Hagen, D. Schönauer, S. Reiß, R. Moos, Zeolites - Versatile Materials for gas sensors, Solid State lonics, 179 (2008) 2416-2423.

[2] Y. Fong, A. Abdullah, A. Ahmad, S. Bhatia, Zeolite Membrane Based Selective Gas Sensors for Monitoring and Control of Gas Emissions, Sensor Letters 5 (2007), 485-499.

[3] R. Moos, R. Müller, C. Plog, A. Knezevic, H. Leye, E. Irion, T. Braun, K.-J. Marquardt, K. Binder, Selective ammonia exhaust gas sensor for automotive applications, Sensors and Actuators B Chem. 83 (2002) 181-189.

[4] G. Hagen, A. Dubbe, F. Rettig, A. Jerger, Th. Birkhofer, R. Müller, C. Plog, R. Moos, Selective impedance based gas sensors for hydrocarbons using ZSM- 5 zeolite films with Chromium(III)oxide interface, Sensors and Actuators B Chem. 119 (2006) 441-448.

[5] G. Hagen, A. Schulz, M. Knörr, R. Moos, Four-Wire Impedance Spectroscopy on Planar Zeolite/Chromium Oxide Based Hydrocarbon Gas Sensors, Sensor 7 (2007), 2681-2692.

[6] A. Dubbe, R. Moos, Electrochem. Solid State Lett. 9, 5 (2006) H31-H34.

[7] A. Tamasi, K. Niesz, I. Palinko, L. Guczi, I. Kiricsi, Modifying the acidic properties of PtZSM-5 and Pt-Y zeolites by appropiately varying reduction methods, in: R. Aiello, G. Giordano, F. Testa (Hrsg.): Studies in Surface Science and Catalysis 142, Elsevier Schience, 2002.

[8] T. Birkhofer, A. Jerger, A. Knezevic, R. Moos, R. Müller, C. Plog, F. Rettig, U. Simon, Gassensor und Verfahren zur Detektion von Kohlenwasserstoffen, insbesondere im Abgas von Kraftfahrzeugen (Gas sensor and method of hydrocarbon detection, particulary in automotive exhausts), German Patent Specification, DE 103,08,799 A1 Priority: February 27, 2003. 